\title{
Pineapple stem by-product as a feed source for growth performance, ruminal fermentation, carcass and meat quality of Holstein steers
}

\author{
C. Hattakum ${ }^{1 \#}$, J. Kanjanapruthipong ${ }^{1}$, S. Nakthong ${ }^{1}$, J. Wongchawalit ${ }^{2}$, P. Piamya ${ }^{3}$ \& \\ S. Sawanon ${ }^{1,3}$ \\ ${ }^{1}$ Department of Animal Science, Faculty of Agriculture at KamphaengSaen, Kasetsart University, \\ NakhonPathom 73140, Thailand \\ ${ }^{2}$ Department of Microbiology, Faculty of Liberal Arts and Science at KamphaengSaen, Kasetsart University, \\ NakhonPathom 73140, Thailand \\ ${ }^{3}$ Centre for Advanced Studies for Agriculture and Food, Kasetsart University Institute for Advanced Studies, \\ Kasetsart University, Bangkok 10900, Thailand
}

(Received 31 January 2018; Accepted 1 January 2019; First published online 14 March 2019)

\author{
Copyright resides with the authors in terms of the Creative Commons Attribution 4.0 South African Licence. \\ See: http://creativecommons.org/licenses/byl4.0/za \\ Condition of use: The user may copy, distribute, transmit and adapt the work, but must recognise the authors and \\ the South African Journal of Animal Science.
}

\begin{abstract}
This experiment was conducted to determine the effects of pineapple stem by-product silage as a feed source in total replacement of Napier or corn silages on growth performance, feed intake and feed efficiency, ruminal fermentation, carcass characteristics and meat quality of Holstein crossbred steers. Forty-eight steers with an average age of 18 months $(448.6 \pm 51.5 \mathrm{~kg}$ ) were randomly allocated to three groups (one diet per group) in a completely randomized design. Steers were fed total mixed ration (TMR) containing a roughage-to-concentrate ratio of $20: 80$. The TMR diets contained Napier grass silage (nTMR), whole corn silage (cTMR) or pineapple stem silage (pTMR) and were offered ad libitum for six months. The results revealed that PTMR and CTMR diets resulted in a significantly higher weight gain than nTMR. These results were observed because pTMR and cTMR diets provided more N-free extract (NFE) total digestible nutrients (TDN) than nTMR diet, and the feed conversion efficiencies for pTMR and cTMR diets were higher than those of nTMR. Ruminal $\mathrm{pH}$, ammonia-nitrogen and volatile fatty acid concentrations were not significantly different among dietary treatments. The carcass characteristics of steers fed cTMR and PTMR diets included significantly larger rib eye areas than steers fed nTMR, whereas meat quality was not affected by treatment. Additionally, the current research showed that PTMR diet provided the lowest feed cost per gain. The results suggest that pineapple stem by-product could be regarded as a potential feed source for reducing costs in cattle feedlots.
\end{abstract}

Keywords: Carcass characteristics, dairy steers; feedlot; industrial waste; total mixed ration

\# Corresponding author: hattakum.2@gmail.com

\section{Introduction}

Holstein steers provide an opportunity for farmers to increase their income by producing beef via feedlots. Feeding strategies of large feedlots and smaller farm-feeders include feeding cattle high-quality forage crops and concentrate to rapidly achieve slaughter weight through supplementation (National Centre for Appropriate Technology, 2010). Moreover, high-quality roughages are reported to improve the growth and meat quality of steers (Kwon et al., 2009). Napier grass has been widely adopted because of its promising high yield that surpasses that of most other tropical grasses. Corn silage is an excellent source of energy and fibre. These forages can be used to increase the nutritional composition of the diet and the growth performance for fattening steers (Ishida et al., 2012), but they have a high cost during the dry season. Thus, there is a need to explore alternative forage sources that are more economical in formulating leastcost rations. Pineapple (Ananas comosus L. Merril) is extensively produced in the world. By-products of pineapple processing consist of residual pulp, peels, stem and skin, and account for a large proportion (70\% - 75\% w/w) of the crop (Suksathit et al., 2011). Dried and ensiled pineapple waste can be used as supplemental roughage and could replace $50 \%$ roughage in the TMR for dairy cattle (Sruamisri, 2007). 
Besides, researchers have focused on the performance and the apparent digestibility of pineapple byproduct when used as feed. Previous studies reported that Brahman $\times$ Thai steers fed silage from pineapple peel mixed with bagasse and vinasse led to increased gross energy and a higher average daily gain (ADG) compared with sweet corn husks and cob silage mixed with bagasse and vinasse (Maneerat et al., 2015). Additionally, Zainuddin et al. (2014) found that the by-product from pineapple stems contained high levels of crude fibre (CF) (average 39.75\%) and carbohydrate (average 41.92\%), but there was no report of feeding pineapple stems to feedlot cattle. Therefore, the present study aimed to investigate the effects of pineapple stem by-product as a feed source on feedlot performance, carcass characteristics and meat quality of Holstein crossbred steers.

\section{Materials and Methods}

This study was conducted at the animal farm of Kasetsart University in Thailand with the approval of Kasetsart University Animal Use Committee (ID number: ACKU 60-AGK-003). Forty-eight Holstein crossbred steers $(75 \%$ Holstein Friesian $\times 25 \%$ Thai native) with an average age of 18 months (live weight $448.6 \pm 51.5$ $\mathrm{kg}$ ) were vaccinated against foot-and-mouth disease, and dewormed to remove internal and ectoparasites. The steers were then randomly allocated to three TMR diets within a completely randomized design, and they were offered the diets ad libitum for six months. Ambient temperature and relative humidity of the housing barn were recorded daily. The temperature humidity index $(\mathrm{THI})$ was calculated using the following equation (Mader et al., 2006).

$$
\mathrm{THI}=(0.8 \times \mathrm{AT})+[(\mathrm{RH} / 100) \times(\mathrm{AT}-14.4)]+46.4
$$

where: AT represents ambient temperature $\left({ }^{\circ} \mathrm{C}\right)$

$\mathrm{RH}$ represents relative humidity (\%)

Pineapple by-product was used to make silage. It consisted of stem residue from bromelain enzyme production and peel residue from canned pineapple production at a $50: 50$ ratio. The pineapple residue was compacted tightly in a two-layered plastic bag at $25 \mathrm{~kg} / \mathrm{bag}$, vacuumed to remove oxygen, and kept for 21 days.

Napier grass silage was prepared from the regrowth of Napier Pakchong 1 grass (Pennisetum purpureum $\times P$. americanum cv. Pakchong 1) at 60 days of maturity and was chopped to 2 to $3 \mathrm{~cm}$ in length with a mechanized forage chopper. The pieces of Napier grass were packed tightly in two-layered plastic bags at $25 \mathrm{~kg} / \mathrm{bag}$, vacuumed to remove oxygen and fermented for 21 days. Whole corn silage was prepared from corn plants at 110 days of maturity. The whole plant corn was chopped and ensiled by the method described.

The silages were sampled at 21 days after closure of the plastic pouches. Sub-samples $(50 \mathrm{~g}$ fresh material) were macerated with $150 \mathrm{~mL}$ of distilled water and stored in a refrigerator at $4{ }^{\circ} \mathrm{C}$ for 12 hours. Then, the extract was filtered (filter paper no. 5, Whatman, England), and the pH of the extract was recorded (Oakton pHTestr 30, USA). Subsequently, the chemical compositions of the samples were determined before mixing with a concentrate ratio of $20: 80$ and 14\% CP-based TMR.

Feed samples of silages and TMRs were ground to pass through a $1 \mathrm{~mm}$ sieve, and their chemical composition was analysed. Dry matter (DM), crude protein (CP), crude fat or ether extract (EE), crude fibre (CF) and total ash were measured according to AOAC (2012). Calcium was analysed with a titration method and phosphorus was analysed with a photometric method according to AOAC (1980). Neutral detergent fibre (NDF) and acid detergent fibre (ADF) were analysed according to Van Soest et al. (1991). N-free extract (NFE) was calculated with the equation NFE (\%) $=100-(\mathrm{CP}+\mathrm{EE}+\mathrm{CF}+\mathrm{ash})$. Total digestible nutrients $(T D N)$ were calculated with the equation TDN\% $=81.38+\left(C P^{*} 0.36\right)-\left(A D F^{*} 0.77\right)$, as described by National Research Council (2001). Hemicellulose and cellulose were calculated as hemicellulose $=\%$ NDR $-\%$ ADR. The ingredients and chemical compositions of three TMRs are shown in Table 1. The pTMR had the lowest $\mathrm{CP}, \mathrm{CF}, \mathrm{NDF}$ and ADF compared with nTMR and cTMR. On the other hand, pTMR contained the highest amounts of NFE and TDN, whereas nTMR had the lowest levels of these chemical compositions. Dry matter intake (DMI), ADG and feed conversion ratio (FCR) were measured to obtain animal performance data. DMI was measured by the differences in the weight before feeding, and the residual feed was recorded for individual animals every day. Steers were weighed at the beginning of the study and then every 30 days until the finish. The means of the initial, final and successive bodyweights for each treatment were recorded throughout the trial at the same intervals to determine the ADG and FCR. 
Table 1 Experimental feed ingredients and chemical compositions of silages and total mixed rations

\begin{tabular}{|c|c|c|c|c|c|c|}
\hline Items & nTMR & cTMR & pTMR & $\begin{array}{l}\text { Napier } \\
\text { silage }\end{array}$ & $\begin{array}{c}\text { Corn } \\
\text { silage }\end{array}$ & $\begin{array}{c}\text { Pineapple } \\
\text { silage }\end{array}$ \\
\hline \multicolumn{7}{|l|}{ Ingredient composition (\%DM) } \\
\hline Napier silage & 20.0 & - & & - & - & - \\
\hline Corn silage & - & 20.0 & - & - & - & - \\
\hline Pineapple by-product silage & & & 20.0 & - & - & - \\
\hline Molasses & 7.0 & 7.0 & 7.0 & - & - & - \\
\hline Urea (46-0-0) & 1.5 & 1.5 & 1.5 & - & - & - \\
\hline Cassava chips & 30.0 & 30.0 & 30.0 & - & - & - \\
\hline Palm kernel expeller meal & 20.9 & 20.9 & 20.9 & - & & - \\
\hline Soybean meal (44\%CP) & 7.9 & 7.9 & 7.9 & - & - & - \\
\hline Corn meal & 10.1 & 10.1 & 10.1 & - & - & - \\
\hline Premix for beef cattle $e^{\underline{a}}$ & 0.5 & 0.5 & 0.5 & - & - & - \\
\hline Sulphur & 0.3 & 0.3 & 0.3 & - & - & - \\
\hline Salt & 0.5 & 0.5 & 0.5 & - & - & - \\
\hline Dicalcium phosphate P-18 & 1.2 & 1.2 & 1.2 & - & - & - \\
\hline Sodium carbonate & 0.1 & 0.1 & 0.1 & - & - & - \\
\hline \multicolumn{7}{|l|}{ Chemical composition (\%DM) } \\
\hline $\mathrm{pH}$ & & & & 4.0 & 3.8 & 3.4 \\
\hline Dry matter & 55.3 & 54.8 & 52.3 & 14.6 & 22.9 & 28.3 \\
\hline Crude protein & 14.0 & 14.8 & 13.7 & 6.6 & 7.7 & 4.6 \\
\hline Crude fat & 1.5 & 1.3 & 1.3 & 2.6 & 1.2 & 0.5 \\
\hline Crude fibre & 21.1 & 17.2 & 12.9 & 36.4 & 26.5 & 13.6 \\
\hline Ash & 6.8 & 6.8 & 5.8 & 13.2 & 5.4 & 3.3 \\
\hline Calcium & 0.7 & 0.8 & 0.8 & 0.6 & 0.7 & 0.5 \\
\hline Phosphorus & 0.4 & 0.5 & 0.5 & 0.2 & 0.2 & 0.1 \\
\hline Neutral detergent fibre & 45.6 & 42.9 & 36.3 & 71.7 & 62.7 & 52.6 \\
\hline Acid detergent fibre & 32.5 & 24.6 & 21.0 & 52.3 & 33.3 & 18.4 \\
\hline Hemicellulose & 13.1 & 18.4 & 15.2 & 19.4 & 29.3 & 34.2 \\
\hline $\mathrm{N}$-free extract & 56.6 & 57.0 & 66.3 & 35.7 & 59.3 & 78.1 \\
\hline Total digestible nutrients & 65.8 & 67.0 & 70.8 & 48.8 & 61.3 & 72.8 \\
\hline
\end{tabular}

${ }^{a}$ Vitamin A: 2160000 IU; vitamin B: 100000 IU; vitamin E: 5000 IU; Mn: 8.5 g; Zn: 6.4 g; Cu: 1.6 g; Mg: 16 g; Co: 320 mg; I: $800 \mathrm{mg}$; Se: $32 \mathrm{mg}$

nTMR: Napier silage as a feed source in total mixed ration

cTMR: whole corn silage as a feed source in total mixed ration

pTMR: pineapple by-product silage as a feed source in total mixed ration

DM: dry matter

CP: crude protein

Ruminal fluid was sampled from 48 steers at the end of the digestion study by suction via mouth. The tube was then passed over the back of the tongue and into the oesophagus, and a vacuum pump was used to apply suction to draw the rumen liquid into the sampling bottle. Ruminal fluid samples were taken four hours after the morning feeding. Ruminal fluid $\mathrm{pH}$ was measured immediately using a portable $\mathrm{pH}$ meter (Oakton pHTestr 30, USA). One millilitre of the rumen samples was centrifuged at $4000 \times g$ for $10 \mathrm{~min}$, and the supernatant was analysed for ammonia nitrogen $\left(\mathrm{NH}_{3}-\mathrm{N}\right)$ using the phenol-hypochlorite method modified from Broderick \& Kang (1980) using a spectrophotometer (Thermo Scientific, Helios Zeta ultraviolet-visible (UV-VIS) model, USA). To determinate volatile fatty acids (VFA), $1 \mathrm{~mL}$ rumen fluid was mixed with $0.2 \mathrm{~mL}$ metaphosphoric acid solution and $40 \mu \mathrm{L}$ crotonic acid solution. After incubation for 30 min at $4{ }^{\circ} \mathrm{C}$, samples 
were centrifuged at $12000 \times g$ for $10 \mathrm{~min}$. The supernatant was collected for analysis using gas chromatography as described by Sawanon (2013).

All Holstein crossbred steers were weighed at the end of the experiment $(635 \pm 38 \mathrm{~kg} \mathrm{BW})$ and then fasted 12 hours, but allowed free access to water before being humanely killed according to Islamic traditions without stunning (National Bureau of Agricultural Commodity and Food Standards, 2007). The weights of the rumen, reticulum, omasum, abomasum and intestine were recorded. Abdominal fat was removed from the abdomen and weighed. To determine kidney fat weight, the fat covering the kidneys was removed and weighed. The warm carcass weight was taken shortly after slaughter. The carcass temperature and $\mathrm{pH}$ level were measured at 1 hour, 24 hours and 7 days post mortem from the muscles of the lumbar region (between the 4th and 5th lumbar vertebrae) using a portable meter with a penetrating electrode probe (TESTO205 pH/temperature meter, Testo Pty Ltd., Croydon South, Victoria, Australia). Two measurements were made for each carcass, according to Orellana et al. (2009). After slaughter, the carcasses were divided into two equal longitudinal halves.

Back fat thickness was measured using callipers on the longissimus dorsi muscle between the 12th and 13th ribs at three quarters of the length of the loin eye muscle from the chine (backbone) according to Orellana et al. (2009).

The ribeye area was measured as the cut surface of the rib eye muscle between the 12th and 13th ribs by tracing the outline onto tracing paper and measuring the area using an LI-3100 Area Meter (LI-3100, Li-COR Biosciences, Lincoln, NE, USA) according to Cacere et al. (2014).

The longissimus dorsi muscle between the 12th and 13th ribs was chilled at $2-4{ }^{\circ} \mathrm{C}$ for 7 days and then weighed to determine the cold carcass weight. Dressing percentage was calculated using the formula reported by Boonsaen et al. (2017):

\section{Dressing percentage $=($ cold carcass weight $\times 100) /$ live weight before slaughter}

Marbling was evaluated by estimating the amount of intramuscular fat visible on the cut surface of the rib eye muscle between the 12th and 13th ribs using photographic standard scales of five values: $1=$ none $2=$ slight, $3=$ small, $4=$ moderate and $5=$ abundant) after chilling for 7 days, according to the Thai Agricultural Commodity and Food Standard (National Bureau of Agriculture Commodity and Food Standards, 2004).

The longissimus dorsi muscle between the 12th and 13th ribs was used to determine meat quality after preservation at $0-4{ }^{\circ} \mathrm{C}$. Two $\mathrm{kg}$ of meat were randomly sampled to detect $\mathrm{pH}$ and temperature at 1 hour, 24 hours and 7 days. The same measurements were collected after preservation at $0-4{ }^{\circ} \mathrm{C}$ for 7 days. Meat quality was assessed using these methods.

The meat samples of the longissimus dorsi muscle between the 12th and 13th ribs were cut at a thickness of $2.5 \mathrm{~cm}$ and then exposed to air for $30 \mathrm{~min}$. After muscle oxygenation, the colour was measured with a colour meter (HunterLab Mini Scan EZ, 4500L, Reston, VA, USA) to determine the colorimetric index of chromaticity. The components of $L^{*}$ (lightness), $a^{*}$ (red-green), and $b^{*}$ (yellowness) were shown in the Hunter colour system and assessed at three points on the muscle surface (Caldara et al., 2013).

A meat sample with a $2.5 \mathrm{~cm}$ thickness was weighed before storage (W1). The meat was then covered with a white cloth and hung at $2-4^{\circ} \mathrm{C}$ for 24 hours. The meat weight was measured after storage (W2). The percentage of drip loss was calculated using the formula:

$$
\text { Drip loss }(\%)=(\mathrm{W} 1-\mathrm{W} 2) \times 100 / \mathrm{W} 1 \text { (Barton-Gade et al., 1993). }
$$

A meat sample with a $2.5 \mathrm{~cm}$ thickness was kept at $-20^{\circ} \mathrm{C}$ for 24 hours and then weighed (W1). The meat was defrosted from freezing at $-20^{\circ} \mathrm{C}$ to $4{ }^{\circ} \mathrm{C}$ and then weighed (W2). The percentage of thawing loss was calculated using the formula:

Thawing loss $(\%)=(\mathrm{W} 1-\mathrm{W} 2) \times 100 / \mathrm{W} 1$ (Eastridge \& Bowker, 2011).

Meat samples with $2.5 \mathrm{~cm}$ thickness were kept at $4{ }^{\circ} \mathrm{C}$ for 24 hours and weighed before boiling (W1). The samples were put in a plastic vacuum-sealed bag to protect the meat from the steam forming inside the bag. The meat in the bag was cooked with hot steam for 15 days until it reached a defined internal temperature of $72{ }^{\circ} \mathrm{C}$, then it was removed from the hot steam and cooled to room temperature. The meat was weighed after boiling (W2), and the percentage of cooking loss was calculated with the formula:

Cooking loss $(\%)=(\mathrm{W} 1-\mathrm{W} 2) \times 100 / \mathrm{W} 1$ (Barton-Gade et al., 1993). 
Core samples for cooking loss were used to determine tenderness by measuring Warner-Bratzler shear force (WBS). The sample was punched parallel to the muscle fibres using a steel hollow-core device with a diameter of $1.27 \mathrm{~cm}$ to obtain six pieces from each muscle sample. The shear force test was performed using a Warner-Bratzler Shear device (Challion, GH Electronics Co., San Francisco, CA, USA). The samples were sheared across the fibre axis using a V-shaped cutting blade with a shearing velocity of $20 \mathrm{~cm} / \mathrm{min}$. The shear force value from each steak was recorded, and the average value was used for evaluation (Jaturasitha et al., 2009).

The meat samples were also analysed after freezing $\left(-20^{\circ} \mathrm{C}\right)$. The frozen sample was weighed before the meat was freeze-dried. The freeze-dried sample was weighed, ground, and the fat content quantified by solvent extraction (petroleum ether, BP $40-60^{\circ} \mathrm{C}$ ) using a Soxhlet apparatus (AOAC International, 2005)

The production cost was determined using the cattle cost, feed cost and total cost for each beast, which was calculated using equations (1) - (3), according to Boonsaen et al. (2017):

$$
\begin{aligned}
& \text { Cattle cost }=\text { initial live weight } \times \text { price of live animal } \\
& \text { Feed cost }=\text { feed intake } \times \text { price of feed } \\
& \text { Total cost }=\text { cattle cost }+ \text { feed cost }+ \text { management cost }
\end{aligned}
$$

where the management cost includes capital investment expenditure (depreciation price of land, building and utensils) and current expenses (wages, medicine, water, electricity, fuel, materials and interest amounts).

The data were analysed using analysis of variance (ANOVA) with the R version 3.3.3 software (R Core Team., 2017) and the means were compared using least significant difference (LSD) tests. The differences in means were considered significant at $P<0.05$. Values of $P>0.05$ and $P<0.10$ indicated a trend, and values of $P>0.10$ were not considered significant.

\section{Results}

Holstein crossbred steers did not differ in their initial weight (Table 2). After 6 months of feeding, the dairy steers fed CTMR and pTMR had higher weight gains at 185.3 and $189.5 \mathrm{~kg}$, respectively, than nTMR $(170.2 \mathrm{~kg})(P<0.05)$. Dairy steers fed cTMR and pTMR had a higher average daily gain $(1.00$ and $1.03 \mathrm{~kg} / \mathrm{d})$ than nTMR $(0.92 \mathrm{~kg} / \mathrm{d})(P=0.09)$. Dairy steers that were fed nTMR and cTMR had higher feed dry matter intake and feed dry matter intake per kilogram of $\mathrm{BW}^{0.75}$ compared with PTMR $(P<0.01)$. However, the steers that were fed nTMR and CTMR had lower feed conversion efficiencies along with higher feed conversion

\begin{tabular}{|c|c|c|c|c|c|}
\hline Items & nTMR & cTMR & pTMR & SEM & $P$-value \\
\hline Number (n) & 16.0 & 16.0 & 16.0 & - & - \\
\hline Initial weight (kg) & 459.0 & 459.8 & 435.3 & 14.27 & 0.42 \\
\hline Final weight $(\mathrm{kg})$ & 629.3 & 645.2 & 634.8 & 17.89 & 0.07 \\
\hline Weight gain (kg) & $170.3^{\mathrm{b}}$ & $185.3^{\mathrm{a}}$ & $189.5^{\mathrm{a}}$ & 10.35 & 0.05 \\
\hline Feed intake $(\mathrm{kg} / \mathrm{d})$ & $11.0^{\mathrm{a}}$ & $9.4^{\mathrm{b}}$ & $7.4^{\mathrm{C}}$ & 0.33 & 0.01 \\
\hline Feed intake (g/kg BW $\left.{ }^{0.75}\right)$ & $96.0^{\mathrm{a}}$ & $85.2^{\mathrm{a}}$ & $70.6^{\mathrm{b}}$ & 0.41 & 0.01 \\
\hline Average daily gain $(\mathrm{kg} / \mathrm{d})$ & 0.9 & 1.0 & 1.0 & 0.05 & 0.09 \\
\hline Feed conversion ratio (feed : gain) & $11.4^{\mathrm{a}}$ & $9.1^{\mathrm{b}}$ & $8.1^{\mathrm{b}}$ & 0.16 & 0.01 \\
\hline
\end{tabular}
ratios at 11.42 and 9.14 compared with pTMR treatment at $8.13(P<0.01)$.

Table 2 Effects of total mixed rations diets on feedlot performance in Holstein crossbred steers

${ }^{a, b, c}$ Means in a row without a common superscript are significantly different $(P<0.05)$

nTMR: Napier silage as a feed source in total mixed ration

CTMR: whole corn silage as a feed source in total mixed ration

pTMR: pineapple by-product silage as a feed source in total mixed ration

Means of ruminal $\mathrm{pH}$ and $\mathrm{NH}_{3}-\mathrm{N}$ concentration were unaffected (Table 3) by dietary treatments (range 6.12 - 6.58, and $3.81-4.37 \mathrm{mg} \%$, respectively). Moreover, the concentration of VFA produced in the rumen, acetic acid (C2), propionic acid (C3) and butyric acid (C4) concentrations were not different $(P>0.05)$ among 
dietary treatments. Additionally, the ratio of $\mathrm{C} 2$ : C3 ranged between 7.16 and 11.06; the difference was not significant $(P>0.05)$.

Table 3 Effects of dietary treatments on rumen fermentation characteristics of dairy steers in feedlot

\begin{tabular}{|c|c|c|c|c|c|}
\hline Items & nTMR & cTMR & pTMR & SEM & $P$-value \\
\hline $\mathrm{pH}$ & 6.1 & 6.6 & 6.1 & 0.18 & 0.16 \\
\hline $\mathrm{NH}_{3}-\mathrm{N}(\mathrm{mg} \%)$ & 3.8 & 4.4 & 4.1 & 0.41 & 0.70 \\
\hline Total VFA (mM/L) & 45.3 & 38.1 & 42.0 & 5.29 & 0.64 \\
\hline Acetate (\%) & 80.8 & 79.3 & 78.0 & 1.87 & 0.78 \\
\hline Propionate (\%) & 8.6 & 9.1 & 11.3 & 1.31 & 0.21 \\
\hline Butyrate (\%) & 11.2 & 10.8 & 10.2 & 1.10 & 0.82 \\
\hline Other VFAs (\%) & 0.5 & 0.6 & 0.4 & 0.07 & 0.64 \\
\hline Acetate : propionate & 11.1 & 9.0 & 7.2 & 1.46 & 0.20 \\
\hline
\end{tabular}

nTMR: Napier silage as a feed source in total mixed ration

CTMR: whole corn silage as a feed source in total mixed ration

pTMR: pineapple by-product silage as a feed source in total mixed ration

Holstein crossbred steers fed pTMR and cTMR had rib eye area of 87.91 and $89.15 \mathrm{~cm}^{2}$, respectively (Table 4), which were significantly larger than steers fed nTMR $(P<0.05)$ with an area of $79.13 \mathrm{~cm}^{2}$. However, feeding with nTMR led to a significantly higher omasum weight $(3.09 \mathrm{~kg})$ than feeding with cTMR $(2.24 \mathrm{~kg})$ and with pTMR $(2.11 \mathrm{~kg})(P<0.01)$. Additionally, none of the meat quality indicators was affected by the TMR diets $(P>0.01)$.

\section{Discussion}

Holstein crossbred steers were fed under an average temperature of $27.3 \pm 2.35^{\circ} \mathrm{C}$, and an average relative humidity of $49.6 \pm 4.83 \%$, according by the measurement method of Dash et al. (2016). This resulted in an average temperature-humidity index (THI) of $77.2 \pm 4.60$ units by substituting in the THI equation of Marder et al. (2006). The THI value of $77.2 \pm 4.60$ indicates a level of mild stress (72-78) in that there was a negative effect of increasing the respiration rate and possibly reducing feed intake (Dash et al., 2016). However, Kwon et al. (2009) reported that good quality roughage could increase growth and meat quality. Pineapple stem by-product silage was used as roughage in comparison with Napier grass and corn silages in this experiment. Moreover, Sruamisri (2007) reported that ensiled pineapple by-product can be used as supplemental roughage and could replace $50 \%$ of the roughage in the total mixed ration (TMR) for dairy cattle.

The silage of pineapple stem by-product was used in total replacement of Napier or corn silage in TMR, which increased weight gain, ADG and feed conversion efficiency when compared with cTMR and nTMR diets. These results of the pTMR diet showed NDF that was lower than CTMR and nTMR diets. Kanjanapruthipong et al. (2001) reported that feed containing high NDF content could decrease ADG of Holstein crossbred dairy cows. Moreover, the pTMR diet had more NFE compared with the nTMR and cTMR diets. Thus Holstein steers fed PTMR diet received a more high-energy diet than steers fed nTMR and cTMR. Accordingly, Maneerat et al. (2015) found that steers (Brahman $\times$ Thai) fed pineapple peel silage mixed with bagasse and vinasse (BP) exhibited the highest ADG level related to the NFE and gross energy of pineapple silage compared with sweet corn silage. Although CP in the PTMR diet was lower than in the cTMR diet, the levels of CP in the TMR diets had no effect on growth performance in the feedlot stage (Boonsaen et al., 2007). Furthermore, pTMR diet had lower CF than those of nTMR and CTMR, according to Van Ackeren et al. (2009), who reported that TMR with lower fibre content led to lower acetate and higher propionate proportions in rumen fermentation characteristics. 
Table 4 Effects of dietary treatments on carcass characteristics and meat quality of steers

\begin{tabular}{|c|c|c|c|c|c|}
\hline Items & nTMR & cTMR & pTMR & SEM & $P$-value \\
\hline Back fat thickness (cm) & 0.9 & 0.9 & 1.0 & 0.13 & 0.43 \\
\hline Rib eye area $\left(\mathrm{cm}^{2}\right)$ & $79.1^{\mathrm{b}}$ & $89.2^{\mathrm{a}}$ & $87.9^{\mathrm{a}}$ & 4.04 & 0.03 \\
\hline Live weight at slaughter (kg) & 609.2 & 625.8 & 603.5 & 20.09 & 0.71 \\
\hline Warm carcass weight (kg) & 341.4 & 350.7 & 364.2 & 21.23 & 0.72 \\
\hline Dressing percentage (\%) & 53.5 & 54.7 & 54.0 & 0.53 & 0.74 \\
\hline Kidney fat (kg) & 18.0 & 17.4 & 14.2 & 1.21 & 0.08 \\
\hline Total fat in abdomen (kg) & 48.6 & 53.6 & 48.6 & 3.30 & 0.49 \\
\hline Intestine (kg) & 13.5 & 11.4 & 11.5 & 0.95 & 0.22 \\
\hline Rumen + reticulum (kg) & 9.8 & 9.5 & 10.9 & 0.43 & 0.07 \\
\hline Omasum (kg) & $3.1^{\mathrm{a}}$ & $2.2^{\mathrm{b}}$ & $2.1^{b}$ & 0.22 & 0.01 \\
\hline Abomasum (kg) & 2.6 & 2.0 & 2.2 & 0.3 & 0.2 \\
\hline Stomach $^{\mathrm{s}}(\mathrm{kg})$ & 15.5 & 13.6 & 15.2 & 0.6 & 0.1 \\
\hline \multicolumn{6}{|l|}{ Carcass pH } \\
\hline $\mathrm{pH}$ at $1 \mathrm{~h}$ & 6.3 & 6.3 & 6.3 & 0.1 & 0.7 \\
\hline $\mathrm{pH}$ at $24 \mathrm{~h}$ & 5.6 & 5.7 & 5.6 & 0.1 & 0.1 \\
\hline $\mathrm{pH}$ at 7 days & 5.7 & 5.6 & 5.7 & 0.1 & 0.8 \\
\hline \multicolumn{6}{|l|}{ Meat quality } \\
\hline Shear force $(\mathrm{N})$ & 39.0 & 43.6 & 39.3 & 7.1 & 0.9 \\
\hline Cooking loss (\%) & 36.4 & 33.2 & 35.4 & 3.5 & 0.2 \\
\hline Drip loss (\%) & 2.3 & 2.2 & 2.1 & 4.0 & 0.2 \\
\hline Thawing loss (\%) & 1.2 & 1.6 & 1.8 & 0.4 & 0.6 \\
\hline \multicolumn{6}{|l|}{ Colour value } \\
\hline$L^{*}$ & 36.0 & 41.3 & 43.3 & 3.2 & 0.3 \\
\hline$a^{*}$ & 15.0 & 13.8 & 13.3 & 0.8 & 0.4 \\
\hline$b^{*}$ & 11.3 & 13.0 & 14.5 & 1.6 & 0.4 \\
\hline Intramuscular fat (\% fresh) & 9.2 & 10.4 & 9.9 & 1.8 & 0.9 \\
\hline Moisture meat (\%) & 64.3 & 63.3 & 63.5 & 1.9 & 0.9 \\
\hline Marbling score & 2.1 & 2.1 & 2.2 & 0.1 & 0.8 \\
\hline
\end{tabular}

${ }^{a, b, c}$ Means in the same row without a common letter in their superscripts differ $(P<0.05)$

${ }^{\mathrm{s}}$ Stomach $=$ rumen + reticulum + omasum + abomasum

$L^{*}$ : lightness; $a^{*}$ : red-green; $b^{*}$ : yellowness

Feeding Holstein crossbred steers with pTMR provided the lowest feed cost per gain at USD 2.59/kg (Table 5), whereas a feed cost per gain of USD $3.53 / \mathrm{kg}$ was observed for steers fed cTMR. Feeding steers with nTMR led to the highest feed cost per $\mathrm{kg}$ of gain at USD3.94 $/ \mathrm{kg}$.

Regarding carcass characteristics, this research demonstrated that feeding pTMR led to a significantly larger rib eye area, compared with nTMR $(P=0.03)$ and had no negative effects on meat quality. These results probably occurred because pTMR and cTMR had higher TDN than nTMR. Similarly, Jeong et al. (2010) found that feed with high TDN (75\% TDN) increased the rib eye area in Hanwoo steers. On the other hand, nTMR provided a significantly higher omasum weight compared with PTMR and CTMR, which caused from the high amount of CF in the intake.

Additionally, the current research found that the feed cost per gain for the pTMR treatment was the lowest because pineapple stem by-product was cheaper than Napier grass and whole corn. Similarly, Maneerat et al. (2015) and Boonsaen et al. (2017) used pineapple peel silage and cassava chips as an energy source in TMR for feedlot cattle because of its cheaper price. Therefore, by-products form pineapple stems have a high potential to serve as low cost feed for cattle raised in feedlots. 
Table 5 Effects of Napier grass silage, whole corn silage and pineapple stem silage in total mixed ration on the production costs of Holstein crossbred steers

\begin{tabular}{lrrr}
\hline Items $^{\text {a }}$ & nTMR & cTMR & pTMR \\
\hline Calf price (USD) & 1530.0 & 1532.8 & 1450.9 \\
Feed cost (USD) & 670.4 & 653.6 & 516.0 \\
Variable cost (USD) & 46.5 & 46.5 & 46.5 \\
Fixed costs (USD) & 16.8 & 16.8 & 16.8 \\
Total cost (USD) & 2263.6 & 2249.6 & 2030.2 \\
Total revenue(USD) & 2057.3 & 2181.6 & 2142.8 \\
Feed cost per gain & 3.9 & 3.5 & 2.6 \\
(USD/kg) & & & \\
\hline
\end{tabular}

${ }^{\text {a}}$ Exchange: USD1 to THB30
nTMR: Napier silage as a feed source in total mixed ration
CTMR: whole corn silage as a feed source in total mixed ration
pTMR: pineapple by-product silage as a feed source in total mixed ration

\section{Conclusions}

This by-product provided growth performance, ruminal fermentation, and carcass and meat quality that did not differ from two popular roughages of Napier grass and whole corn. However, the use of pineapple stem by-product as a feed source reduced feed costs.

\section{Acknowledgements}

This work was partially supported by the Thailand Research Fund (TRF) with project ID RDG5820027 and the Centre for Advanced Studies for Agriculture and Food, Institute for Advanced Studies, Kasetsart University under the Higher Education Research Promotion and National Research University Project of Thailand, Office of the Higher Education Commission, Ministry of Education, Thailand.

\section{Authors' contributions}

$\mathrm{CH}$ designed the experiment, carried out the animal experiment, data analysis and laboratory analysis. PP participated in laboratory analysis, while SS, JK, SN and JW participated in statistics and interpretation. $\mathrm{CH}$ wrote and revised the manuscript, while SS suggested the revision.

\section{Conflict of interest declaration}

None of the authors has any conflict of interest to declare.

\section{References}

AOAC, 1980. Official methods of analysis. 13th edition. Association of Official Analytical Chemists, Arlington, VA.

AOAC International, 2005. Official methods of analysis. 18th edition. Association of Official Analytical Chemists, Washington DC.

AOAC, 2012. Official methods of analysis. 19th edition. Association of Official Analytical Chemists, Arlington, VA.

Barton-Gade, P.A., Demeyer, D., Honikel, K.O., Joseph, R.L., Poulame, E., Severini, M., Smulder, F.J. \& Tonberg, E., 1993. Reference method for water holding capacity in meat and meat products. Procedures Recommended by an OECD Working Group. 39th International Congress of Meat Science and Technology. 1-6 August 1993, Calgary, Alberta, Canada.

Boonsaen, P., Soe, N.W., Maitreejet, W., Majarune, S., Reungprim, T. \& Sawanon, S., 2017. Effects of protein levels and energy sources in total mixed ration on feedlot performance and carcass quality of KamphaengSaen steers. Agric. Nat. Resour. 51, 57-61.

Broderick, G.A. \& Kang, J.H., 1980. Automated simultaneous determination of ammonia and total amino acids in ruminal fluid and in vitro media. J. Dairy Sci. 63, 64-75.

Cacere, R.A.S., Morais, M.G., Alves, F.V., Feijó, G.L.D., Ítavo, C.C.B.F., Ítavo, L.C.V., Oliveira, L.B. \& Ribeiro, C.B., 2014. Quantitative and qualitative carcass characteristics of feedlot ewes subjected to increasing levels of concentrate in the diet. Arq. Bras. Med. Vet. Zootec. 66, 1601-1610.

Caldara, F.R., Moi, M., Dos Santos, L.S., de Lima Almeida Paz, I.C., Garcia, R.G., de Alencar Nääs, I. \& Fernandes, A.R., 2013. Carcass characteristics and qualitative attributes of pork from immunocastrated animals. AsianAustralas. J. Anim. Sci. 26, 1630-1636.

Dash, S., Chakravarty, A.K., Singh, A., Upadhyay, A., Singh, M. \& Yousuf, S., 2016. Effect of heat stress on reproductive performances of dairy cattle and buffaloes: A review. Vet. World 9, 235-244. 
Eastridge, J.S. \& Bowker, B.C., 2011. Effect of rapid thawing on the meat quality attributes of USDA select beef strip loin steaks. J. Food Sci. 76, S156-S162.

Ishida, K., Yani, S., Kitagawa, M., Oishi, K., Hirooka, H. \& Kumagai, H., 2012. Effects of adding food by-products mainly including noodle waste to total mixed ration silage on fermentation quality, feed intake, digestibility, nitrogen utilization and ruminal fermentation in wethers. Anim. Sci. J. 83, 735-742.

Jaturasitha, S., Norkeaw, R., Vearasilp, T., Wicke, M. \& Kreuzer, M., 2009. Carcass and meat quality of Thai native cattle fattened on Guinea grass (Panicum maxima) or Guinea grass-legume (Stylosanthes guianensis) pastures. Meat Sci. 81, 155-162.

Jeong, J., Seong, N.I., Hwang, I.K., Lee, S.B., Yu, M.S., Nam, I.S. \& Lee, M.I., 2010. Effects of level of CP and TDN in the concentrate supplement on growth performances and carcass characteristics in Hanwoo steers during final fattening period. J. Anim. Sci. Technol. 52, 305-312.

Kanjanapruthipong, J., Buatong, N. \& Buaphan, S., 2001. Effects of roughage detergent fiber on dairy performance under tropical conditions. Asian-Australas. J. Anim. Sci. 14, 1400-1404.

Kwon, E.G., Park, B.K., Kim, H.C., Cho, Y.M., Kim, T.I., Chang, S.S., Oh, Y.K., Kim, N.K., Kim, J.H., Kim, Y.J., Kim, E.J., Im, S.K. \& Choi, N.J., 2009. Effects of fattening period on growth performance, carcass characteristics and lipogenic gene expression in Hanwoo steers. Asian-Australas. J. Anim. Sci. 22, 1654-1660.

Mader, T.L., Davis, M.S. \& Brown-Brandl, T., 2006. Environmental factors influencing heat stress in feedlot cattle. J. Anim. Sci. 84, 712-719.

Maneerat, W., Prasanpanich, S., Tumwasorn, S., Laudadio, V. \& Tufarelli, V., 2015. Evaluating agro-industrial byproducts as dietary roughage source on growth performance of fattening steers. Saudi J. Biol. Sci. 22, 580-584.

National Bureau of Agriculture Commodity and Food Standards, 2004. Thai agricultural commodity and food standard TACFS6001: Beef. Ministry of Agriculture and Cooperatives, Bangkok, Thailand.

National Bureau of Agricultural Commodity and Food Standards, 2007. Halal food - Thai agricultural standard. Available at: http://www.halalrc.org/images/Research\%20Material/Report/HALAL\%20FOOD-Agricultural\%20Standards.pdf. Accessed 6 January 2019.

National Centre for Appropriate Technology (NCAT), 2010. Dairy beef. National Sustainable Agriculture Information Service. Available at: https://attra.ncat.org/livestock/\#guide. Accessed 5 May 2017.

National Research Council, 2001. Nutrient requirements of dairy cattle. 7th edition. National Research Council, Washington, DC.

Orellana, C., Peña, F., García, A., Perea, J., Martos, J., Domenech, V. \& Acero, R., 2009. Carcass characteristics, fatty acid composition, and meat quality of Criollo Argentino and Braford steers raised on forage in a semi-tropical region of Argentina. Meat Sci. 81, 57-64.

R Core Team, 2017. R: A language and environment for statistical computing. Version 3.3.3. R Foundation for Statistical Computing, Vienna, Austria. https://www.R-project.org/. Accessed 6 January 2019.

Sawanon, S., 2013. Organic Beef Production. Kasetsart University Press, Bangkok, Thailand.

Sruamisri, S., 2007. Agricultural wastes as dairy feed in Chiang Mai. Animal Sci. J. 78, 335-341.

Suksathit, S., Wachirapakorn, C. \& Opatpatanakit, Y., 2011. Effects of levels of ensiled pineapple waste and pangola hay fed as roughage sources on feed intake, nutrient digestibility and ruminal fermentation of Southern Thai native cattle. Songklanakarin J. Sci. Technol. 33, 281-289.

Van Ackeren, C.V., Steingaß, H., Hartung, K., Funk, R. \& Drochner, W., 2009. Effect of roughage level in a total mixed ration on feed intake, ruminal fermentation patterns and chewing activity of early-weaned calves with ad libitum access to grass hay. Anim. Feed Sci. Technol. 153, 48-59.

Van Soest, P.J., Robertson, J.B. \& Lewis, B.A., 1991. Methods for dietary fiber, neutral detergent fiber, and nonstarch polysaccharides in relation to animal nutrition. J. Dairy Sci. 74, 3583-3597.

Zainuddin, M.F., Shamsudin, R., Mokhtar, M.N. \& Ismail, D., 2014. Physicochemical properties of pineapple plant waste fibre from the leaves and stems of different varieties. Bio Resources 9, 5311-5324. 